\title{
Performance Study of Ethanol Blended Gasoline Fuel in Spark Ignition Engine
}

\author{
Jitendra kumar ${ }^{1}$, Dhananjay trivedi ${ }^{2}$, Prakash Mahara ${ }^{3}$, Ravi Butola ${ }^{4}$ \\ 1,2,3,4 M.Tech Scholars, Department of Mechanical Engineering, Delhi Technological University, \\ New Delhi-110042, India
}

\begin{abstract}
Growing energy needs and environmental concern worldwide have propelled the interest for quest and utilization of renewable and eco friendly fuels.Various substitutes are available to be used engines with the possibility of reducing harmful emissions. In this work gasoline is taken as reference which is blended with ethanol. Physical properties relevant to the fuel were determined for the four blends of gasoline and ethanol. A four cylinder, four stroke, varying rpm, Petrol engine connected to eddy current type dynamometer was run on blends containing 5\%,10\%,15\%,20\% ethanol and performance characteristics were evaluated. In this paper it is shown that the higher blends can replace gasoline in a SI engine, results showed that there is a reduction in exhaust gases and increase in Mechanical efficiency, Specific Fuel Consumption and air fuel ratio on blending. We can conclude from the result that using 10\% ethanol blend is most effective and we can utilize it for further use in SI engines with little constraint on material used to sustain little increase in pressure. Keywords: Spark Ignition Engine, Ethanol, mechanical efficiency, specific fuel consumption, Gasoline etc.
\end{abstract}

\section{INTRODUCTION}

Rapidly increase in fuel prices and oil consumption along with scarcity of petroleum based fuels have accelerated an interest for search of alternative, renewable sources of fuel like biodiesel and alcohol-based fuels. In recent years ethanol is has become widely used renewable fuel with up to $10 \%$ by volume blended in to gasoline for regular engines or up to $85 \%$ for use in Flex-Fuel vehicles designed to run with higher concentrations of ethanol. Ethanol can also be used as a neat fuel in spark-ignition engines or blended up to $40 \%$ with Diesel fuel for use in compression-ignition engines [1-2].Ethanol is biodegradable, less pernicious to ground water, and has an octane number much higher than gasoline as well as having safer effect on vehicle emissions [3]. Environmental issues regarding the emissions of hydrocarbon, carbon dioxide, carbon monoxide, nitrogen oxides and particulate matter from petroleum based fuels such as gasoline and diesel are of serious concern worldwide. These emissions are not only have adverse effect on human body but also harmful to the environment as they vital role in formation of the greenhouse effect, acid rain and global warming. Therefore there is an acute need for renewable and environment friendly alternative fuels such as ethanol (alcohol), natural gas, and biodiesel. Today, the transport sector is a major contributor to net emissions of greenhouse gases, of which carbon dioxide is particularly important. The carbon dioxide emissions originate mainly from the use of fossil fuels; mostly gasoline and diesel oil in road transportation systems, although some originates from other types of fossil fuels such as natural gas and Liquefied Petroleum Gas (LPG). If international and national goals (such as those set out in the Kyoto protocol) for reducing net emissions of carbon dioxide are to be met, the use of fossil fuels in the transport sector has to be substantially reduced. This can be done, to some extent, by increasing the energy efficiency of engines and vehicles and thus reducing fuel consumption on a volume per unit distance travelled basis. However, since the total transportation work load is steadily increasing such measures will not be sufficient if we really want to reduce the emissions of carbon dioxide.

\section{Literature Review}

N. Seshaiah et al [4] tested the variable compression ratio spark ignition engine designed to run on gasoline with pure gasoline, LPG (Isobutene), and gasoline blended with ethanol 10\%, 15\%, 25\% and 35\% by volume. Also, the gasoline mixed with kerosene at $15 \%, 25 \%$ and $35 \%$ by volume without any engine modifications has been tested and presented the result. Brake thermal and volumetric efficiency variation with brake load is compared. $\mathrm{CO}$ and $\mathrm{CO}_{2}$ emissions have been also compared for all tested fuels. It is observed that the LPG is a promising fuel at all loads lesser carbon monoxide emission compared with other fuels tested. Using ethanol as a fuel additive to the mineral gasoline, (up to $30 \%$ by volume) without any engine modification and without any loses of efficiency, it has been observed that the petrol mixed with ethanol at $10 \%$ by volume is better at all loads and compression ratios. Juozas Grabys[5] investigated experimentally and compare the 
engine performance and pollutant emission of a SI engine using ethanol-gasoline blended fuel and pure gasoline. The results showed that when ethanol was added, the heating value of the blended fuel decreases, while the octane number of the blended fuel increases. The results of the engine test indicated that when ethanol-gasoline blended fuel was used, the engine power and specific fuel consumption of the engine slightly increase; $\mathrm{CO}$ emission decreases dramatically as a result of the leaning effect caused by the ethanol addition; $\mathrm{HC}$ emission decreases in some engine working conditions; and $\mathrm{CO}_{2}$ emission increases because of the improved combustion. Bang-Quan He, Jian-Xin Wang [6] investigated the effect of ethanol blended gasoline fuels on emissions and catalyst conversion efficiencies in a spark ignition engine with an electronic fuel injection (EFI) system. Result showed that ethanol can decrease engine-out regulated emissions. The fuel containing $30 \%$ ethanol by volume can drastically reduce engine-out total hydrocarbon emissions(THC) at operating conditions and engine-out $\mathrm{THC}, \mathrm{CO}$ and $\mathrm{NO}_{\mathrm{x}}$ emissions at idle speed, but unburned ethanol and acetaldehyde emissions are effective in reducing acetaldehyde emissions; but the conversion of unburned ethanol is low. Tailpipe emissions of THC, $\mathrm{CO}$ and $\mathrm{NO}_{\mathrm{x}}$ have close relation to engine-out emissions, catalyst conversion efficiency, engine's speed and load, air/fuel equivalence ratio. Moreover, the blended fuels can decrease brake septic energy consumption. Amit Pal, S. Maji, O.P. Sharma and M.K.G.Babu [7] operated a Kirloskar, four stroke, $7.35 \mathrm{~kW}$, twin cylinder, DI diesel engine in dual fuel mode (with substitution of up to $75 \%$ diesel with CNG). The results of this experiment of substituting the diesel by CNG at different loads showed significant reduction in smoke, 10 to $15 \%$ increase in power, 10 to $15 \%$ reduction in fuel consumption and 20 to $40 \%$ saving in fuel cost (considering low cost of CNG). The most exciting result was about 33\% reduction in engine noise which may prolong the engine life significantly and the consequent sound levels of giant diesel engine reduced to that of a similarly sized gasoline engine. P. A. Hubballi, and T.P. Ashok Babu [8] investigated experimentally the effect of Denatured spirit (DNS) and DNS-Water blends as fuels in a four cylinder four stroke SI engine. Performance tests were conducted to study Brake Thermal Efficiency (BThE), Brake Power (BP), Engine Torque (T) and Brake Specific Fuel Consumption (BSFC). Exhaust emissions were also investigated for carbon monoxide $(\mathrm{CO})$, hydrocarbons $(\mathrm{HC})$, oxides of nitrogen $\left(\mathrm{NO}_{\mathrm{x}}\right)$ and carbon dioxide $\left(\mathrm{CO}_{2}\right)$. The results of the experiments reveled that, both DNS and DNS95W5 as fuels increase BThE, BP, engine torque and BSFC. The $\mathrm{CO}, \mathrm{HC}, \mathrm{NO}_{\mathrm{x}}$ and $\mathrm{CO}_{2}$ emissions in the exhaust decreased. The DNS and DNS95W5 as fuels produced the encouraging results in engine performance and mitigated engine exhaust emissions. Hakan Bayraktar[9]studied the effects of ethanol addition to gasoline on an SI engine performance and exhaust emissions are investigated experimentally and theoretically. In the theoretical study, a quasidimensional SI engine cycle model, which was firstly developed for gasoline-fuelled SI engines was adapted for SI engines running on gasoline-ethanol blends. Experimental applications were carried out with the blends containing $1.5,3,4.5,6,7.5,9,10.5$ and 12 vol\% ethanol. Numerical applications were performed up to 21 $\mathrm{vol} \%$ ethanol. Engine was operated with each blend at $1500 \mathrm{rpm}$ for compression ratios of 7.75 and 8.25 and at full throttle setting. Experimental results showed that among the various blends, the blend of $7.5 \%$ ethanol was the most suitable one from the engine performance and $\mathrm{CO}$ emissions points of view. However, theoretical comparisons showed that the blend containing $16.5 \%$ ethanol was the most suited blend for SI engines.

Furthermore, it was demonstrated that the proposed SI engine cycle model has an ability of computing SI engine cycles when using ethanol and ethanol-gasoline blends and it can be used for further extensive parametric studies.

\subsection{Performance of I.C Engines}

\section{Performance Of I.C Engines}

Fuel-air (F/A) or air-fuel (A/F) ratio (lamda): The relative proportions of the fuel and air in the engine are very important from standpoint of combustion and efficiency of the engine. This is expressed either as the ratio of the mass of the fuel to that of the air or vice versa.

$$
\text { Air fuel ratio: } \quad \mathrm{A} / \mathrm{F}=\frac{\text { Air flow }}{\text { Fuel flow }} .
$$

Specific fuel consumption (SFC): Brake specific fuel consumption and indicated specific fuel consumption, abbreviated BSFC and ISFC, are the fuel consumptions on the basis of Brake power and Indicated power respectively.

Brake specific fuel consumption $(\mathrm{Kg} / \mathrm{kwh}): \quad \mathrm{BSFC}=\frac{\text { Fuel flow in } \mathrm{kg} / \mathrm{hr}}{\mathrm{BP}}$.

Mechanical efficiency $\left(\eta_{\mathrm{m}}\right)$ : Mechanical efficiency is the ratio of brake horse power(delivered power) to the indicated horsepower (power provided to the piston):

Mechanical efficiency:

$$
\eta_{\mathrm{m}}=\frac{\text { Brake Power }}{\text { Indicated Power }}
$$

\section{Experimental Set Up}

The setup consists of four cylinders, four strokes, and Petrol (MPFI) engine connected to eddy current type dynamometer for loading. It is provided with necessary instruments for combustion pressure and crank- 
angle measurements. These signals are interfaced to computer through engine indicator for $\mathrm{P}_{\theta}-\mathrm{P}_{\mathrm{V}}$ diagrams. Provision is also made for interfacing airflow, fuel flow, temperatures and load measurement. The set up has stand-alone panel box consisting of air box, fuel tank, manometer, fuel measuring unit, transmitters for air and fuel flow measurements, process indicator and engine indicator Rotameters are provided for cooling water and calorimeter water flow measurement. The setup enables study of engine performance for brake power, indicated power, frictional power, BMEP, IMEP, brake thermal efficiency, indicated thermal efficiency, Mechanical efficiency, volumetric efficiency, specific fuel consumption, A/F ratio and heat balance. Windows based Engine Performance Analysis software package "Enginesoft" is provided for online performance evaluation.

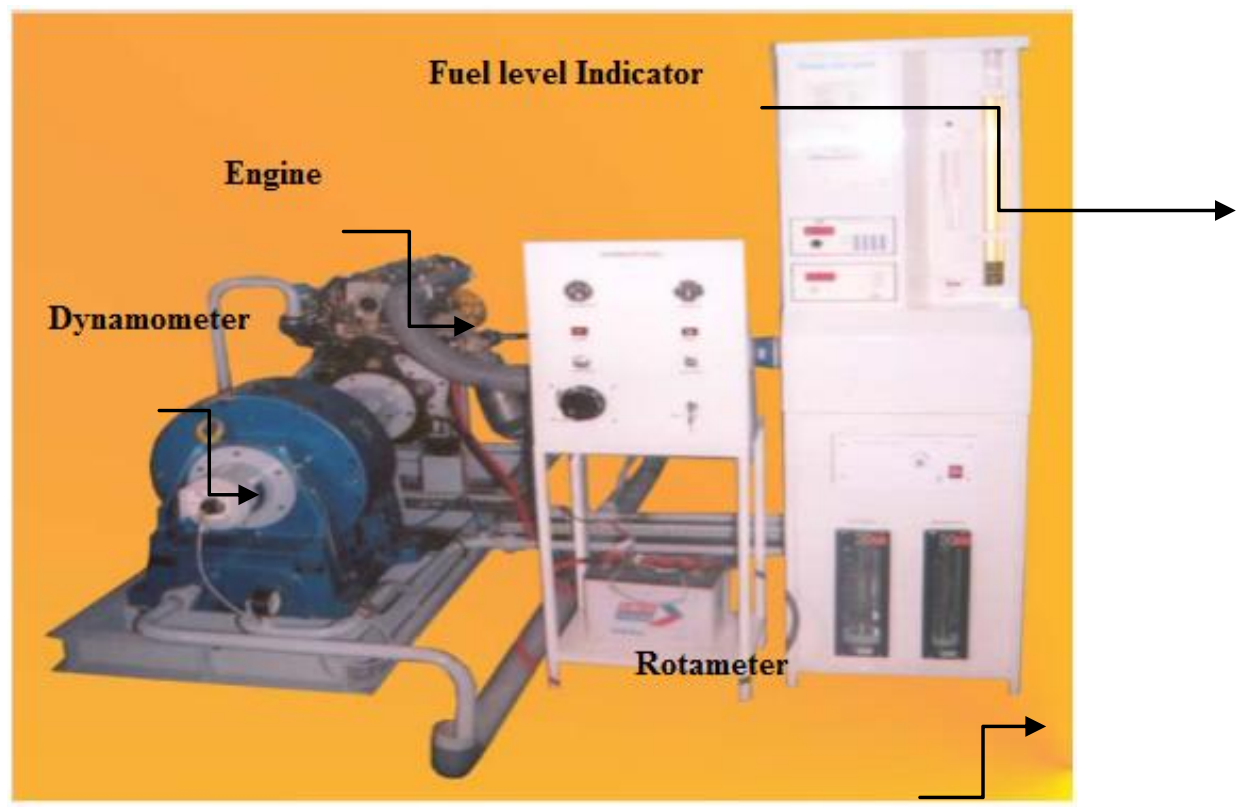

Fig 4.1 Diagram of Setup used

\subsection{Procedure}

Ensure cooling water circulation for eddy current dynamometer, Piezosensor, engine cooling and calorimeter. Start the set up and run the engine at no load for 4-5 minutes. Switch on the computer and run "Enginesoft". Confirm that the Enginesoft configuration data is as given below. Gradually increase throttle to full open condition and load the engine simultaneously maintaining engine speed at @ 5000 RPM. Wait for steady state (for @ 3 minutes) and log the data in the "Enginesoft". Gradually increase the load to decrease the speed in steps of @500 RPM up to@2000 rpm maximum and repeat the data logging for each observation. Note the reading of Exhaust Gas using Exhaust Gas Analyzer at exhaust. View the results and performance plots in "Enginesoft".

\subsection{Enginesoft Configuration data:}

\subsubsection{Engine and set up details}

\begin{tabular}{|l|l|}
\hline Engine power & $47.7 \mathrm{KW}$ \\
\hline Engine max speed & $6200 \mathrm{RPM}$ \\
\hline Cylinder bore & $68.5 \mathrm{~mm}$ \\
\hline Stroke length & $72 \mathrm{~mm}$ \\
\hline Connecting rod length & $112.5 \mathrm{~mm}$ \\
\hline Compression ratio & $9.2: 1$ \\
\hline Stroke type & Four \\
\hline No. of cylinders & Four \\
\hline Speed type & Variable \\
\hline Cooling type & Water \\
\hline Dynamometer type & Eddy current \\
\hline Indicator used type & Cylinder pressure \\
\hline Interface type used & PCI-1050 \\
\hline Calorimeter used & Pipe in pipe \\
\hline
\end{tabular}

Table 4.3.1 Set up details 


\subsubsection{Theoretical constants:}

\begin{tabular}{|l|l|}
\hline Fuel density & $740 \mathrm{~kg} / \mathrm{m}^{3}$ \\
\hline Calorific value & $44000 \mathrm{~kJ} / \mathrm{kg}$ \\
\hline $\begin{array}{l}\text { Orifice coefficient of } \\
\text { discharge }\end{array}$ & 0.60 \\
\hline Sp heat of exhaust gas & $1.00 \mathrm{~kJ} / \mathrm{kg}-\mathrm{K}$ \\
\hline Max sp heat of exhaust gas & $1.25 \mathrm{~kJ} / \mathrm{kg}-\mathrm{K}$ \\
\hline Min sp heat of exhaust gas & $1.00 \mathrm{~kJ} / \mathrm{kg}-\mathrm{K}$ \\
\hline Specific heat of water & $4.186 \mathrm{~kJ} / \mathrm{kg}-\mathrm{K}$ \\
\hline Water density & $1000 \mathrm{~kg} / \mathrm{m}^{3}$ \\
\hline Ambient temperature & $300 \mathrm{C}$ \\
\hline
\end{tabular}

Table 4.3.2 Theoretical Constants

\subsubsection{Sensor range}

\begin{tabular}{|l|l|}
\hline $\begin{array}{l}\text { Exhaust gas temp. trans. } \\
\text { (Engine) }\end{array}$ & $0-1200 \mathrm{C}$ \\
\hline Air flow transmitter & $-200-0 \mathrm{~mm} \mathrm{WC}$ \\
\hline Fuel flow DP transmitter & $0-500 \mathrm{~mm} \mathrm{WC}$ \\
\hline Load cell & $0-50 \mathrm{~kg}$ \\
\hline $\begin{array}{l}\text { Cylinder pressure } \\
\text { transducer }\end{array}$ & $0-345.5 \mathrm{bar}$ \\
\hline
\end{tabular}

Table 4.3.3 Sensor Range

\section{Results And Discussion}

\subsection{No Load Test}

Lamda increases from 1 to 1.2 as blending increased up to $15 \%$.It increases by $22 \%$ at $2500 \mathrm{rpm}$ for $10 \%$ blend in comparison to commercial Gasoline as shown fig 5.1.

$>$ Specific Fuel Consumption increases on blending Gasoline. In comparison to commercial Gasoline, it increases by $7.2 \%$ for $10 \%$ blend, $8.0 \%$ for $15 \%$ blend and $18.77 \%$ for $20 \%$ blend at $2100 \mathrm{rpm}$ as shown in fig 5.2.

$>$ Mechanical Efficiency increases on blending Gasoline. In comparison to commercial Gasoline, it increases by $9 \%$ for $10 \%$ blend, $8.8 \%$ for $15 \%$ blend and $4.85 \%$ for $20 \%$ blend at $5000 \mathrm{rpm}$ as shown in fig 5.3 .

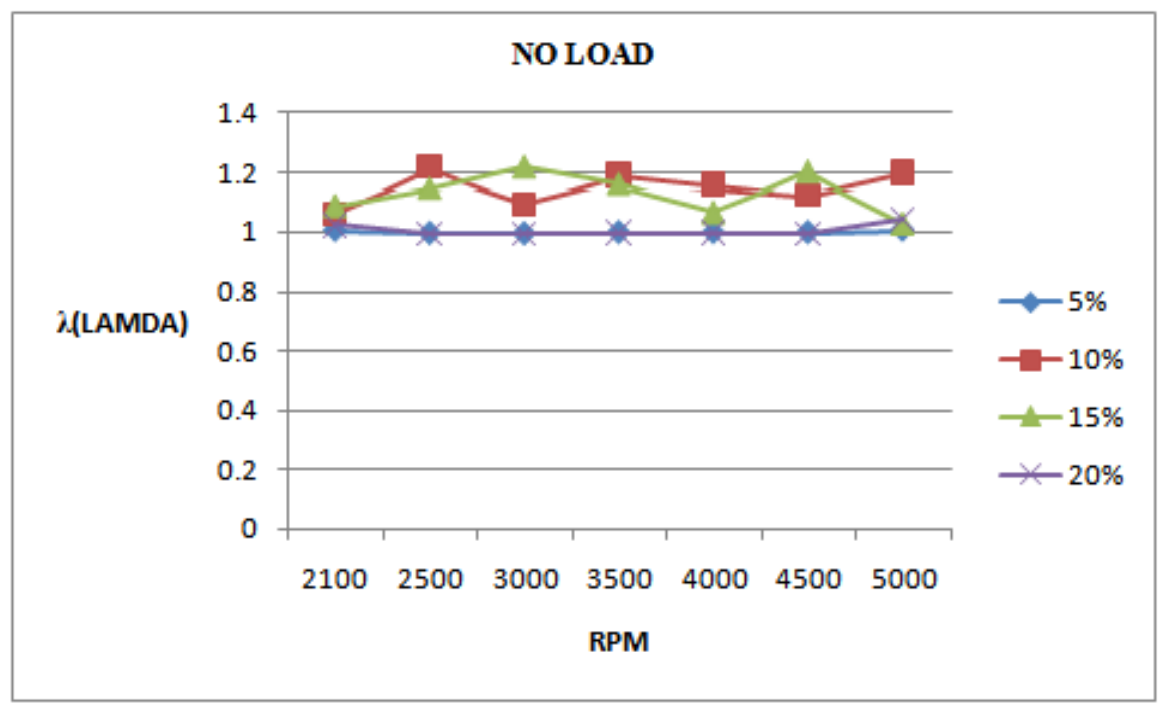

Fig 5.1.1 Lamda variations with blends at different rpm. 


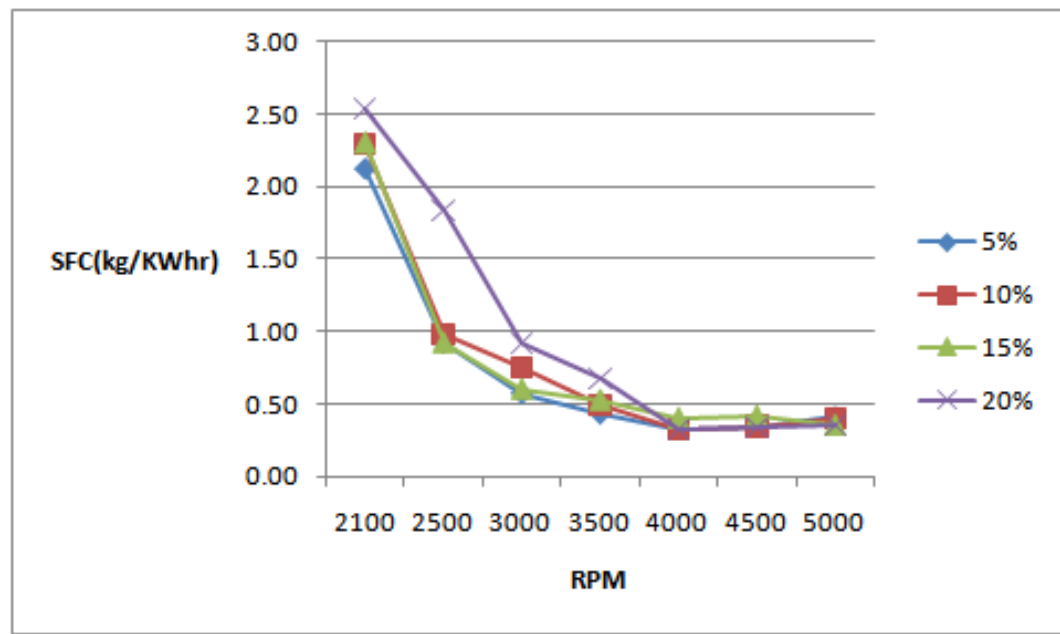

Fig 5.1.2 Specific fuel consumption variation with blends at different rpm.

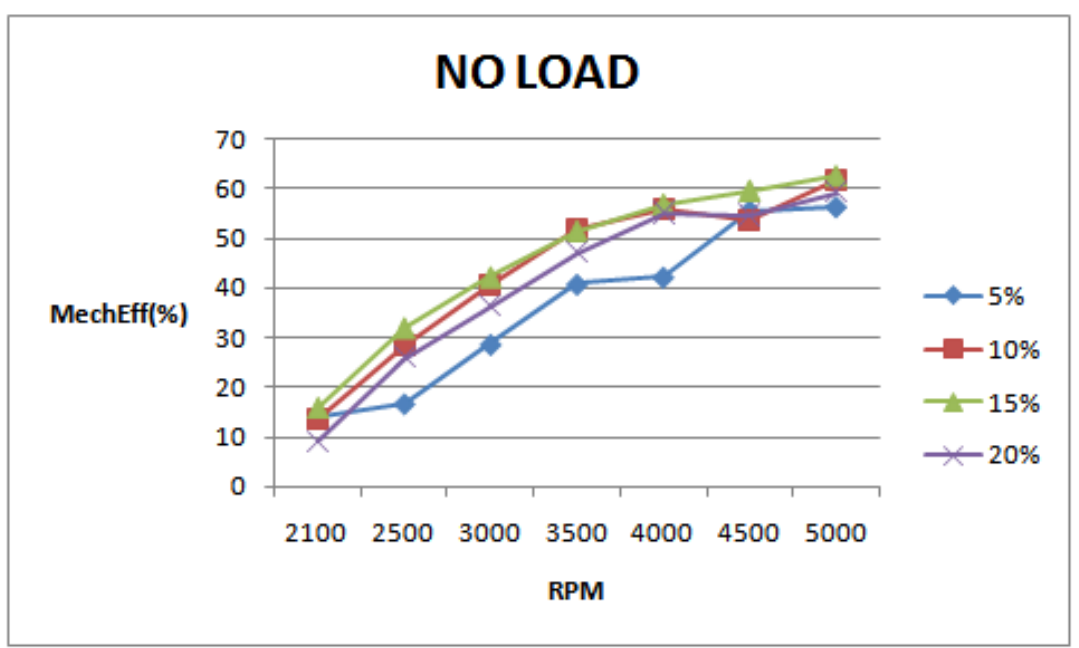

Fig 5.1.3 Mechanical efficiency variation with blends at different rpm.

\subsection{Constant rpm Test}

$>$ Lamda decreases on blending at high loads and generally lies between 0.992 to 0.996 for $3000 \mathrm{rpm}$ and $4000 \mathrm{rpm}$ as shown in fig 5.2.1 and 5.2.2.

$>$ Mechanical Efficiency increases with blending and is slightly greater at $4000 \mathrm{rpm}$. At $20 \mathrm{~kg}$ load, it increases by $11.85 \%$ for $10 \%$ blend, $5.5 \%$ for $15 \%$ blend, $10.99 \%$ for $20 \%$ blend at $3000 \mathrm{rpm}$ and increase by $3.36 \%$ for $10 \%$ blend, $2.89 \%$ for $15 \%$ blend and $1.03 \%$ for $20 \%$ blend at 4000 rpm with respect to commercial Gasoline as shown in fig 5.2.3 and 5.2.4.

$>$ Specific Fuel Consumption increases on blending and is generally lower for $4000 \mathrm{rpm}$. At 20kg load, it increases by $5.66 \%$ for $10 \%$ blend, $14.55 \%$ for $15 \%$ blend, $40.16 \%$ for $20 \%$ blend at $3000 \mathrm{rpm}$ and increase by $0.75 \%$ for $10 \%$ blend, $2.47 \%$ for $15 \%$ blend and $20.47 \%$ for $20 \%$ blend at $4000 \mathrm{rpm}$ with respect to commercial Gasoline as shown in fig 5.2.5 and 5.2.6. 


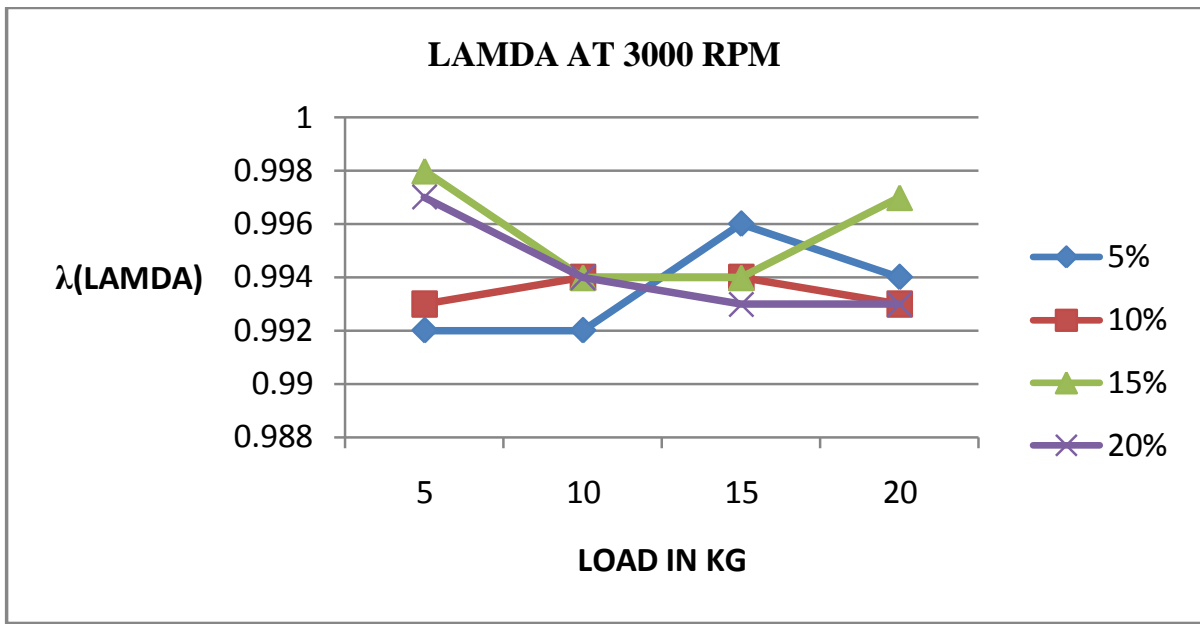

Fig 5.2.1 Variation of Lambda emission with load at $3000 \mathrm{rpm}$

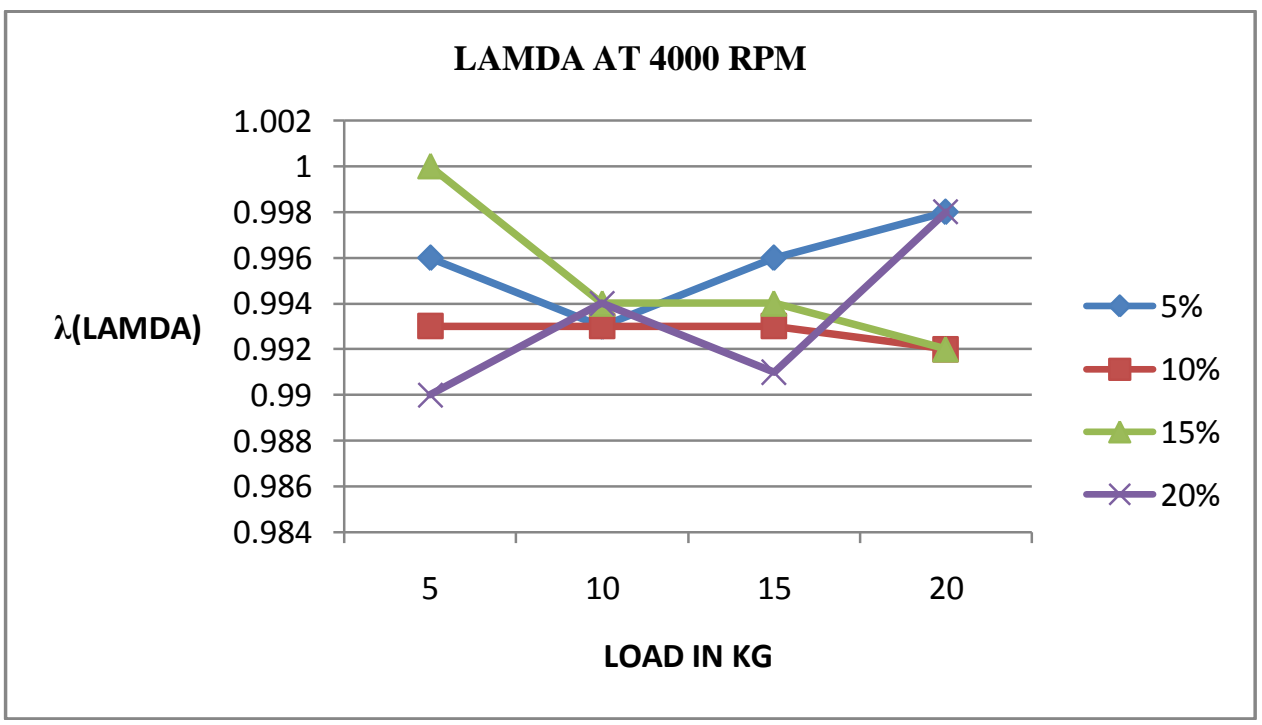

Fig 5.2.2 Variation of Lamda emission with load at $4000 \mathrm{rpm}$

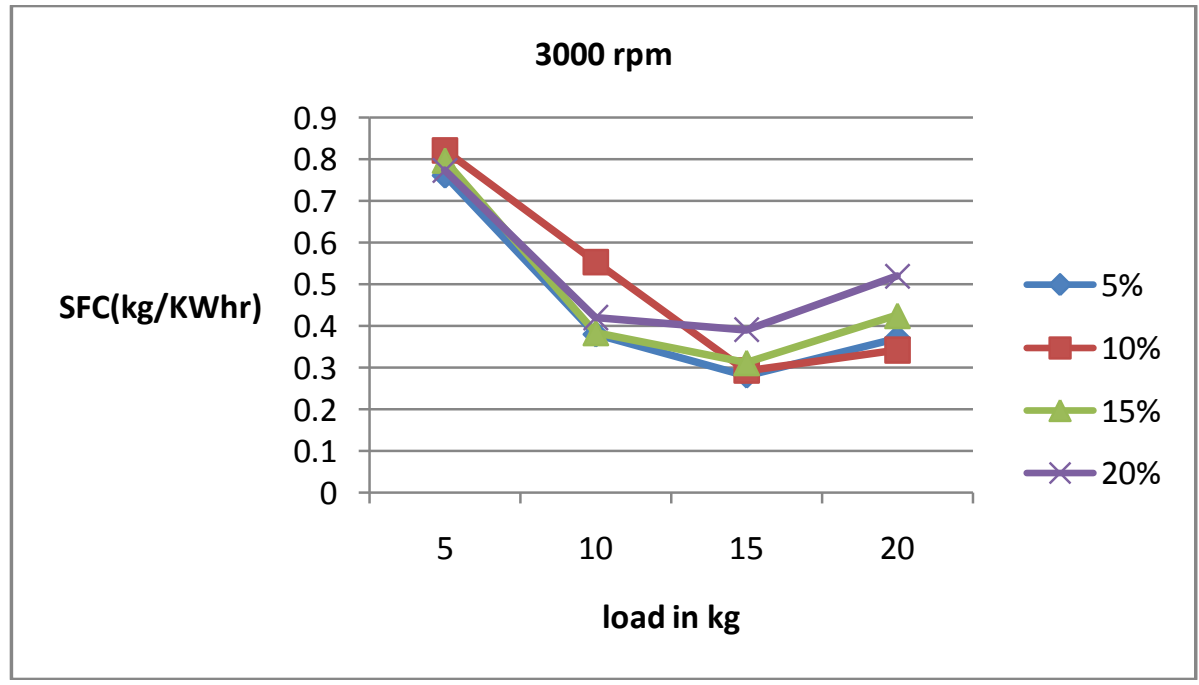

Fig 5.2.3 Variation of Specific fuel consumption with load at $3000 \mathrm{rpm}$ 


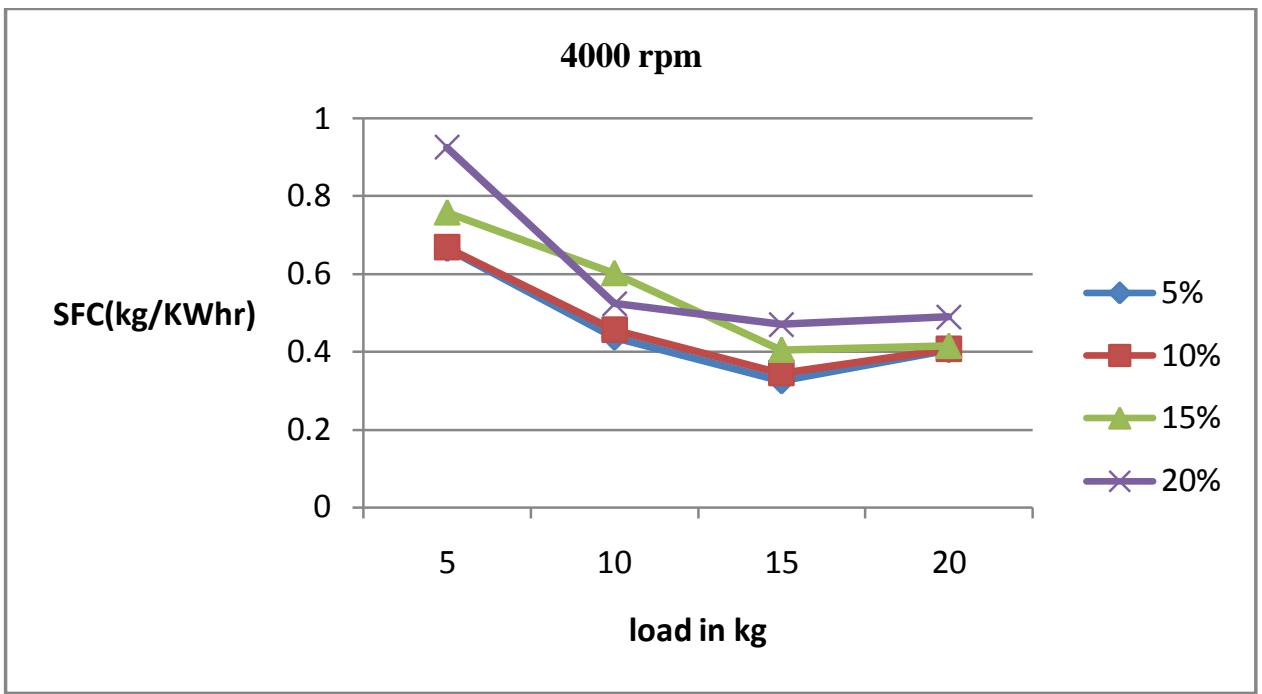

Fig 5.2.4 Variation of Specific fuel consumption with load at $4000 \mathrm{rpm}$

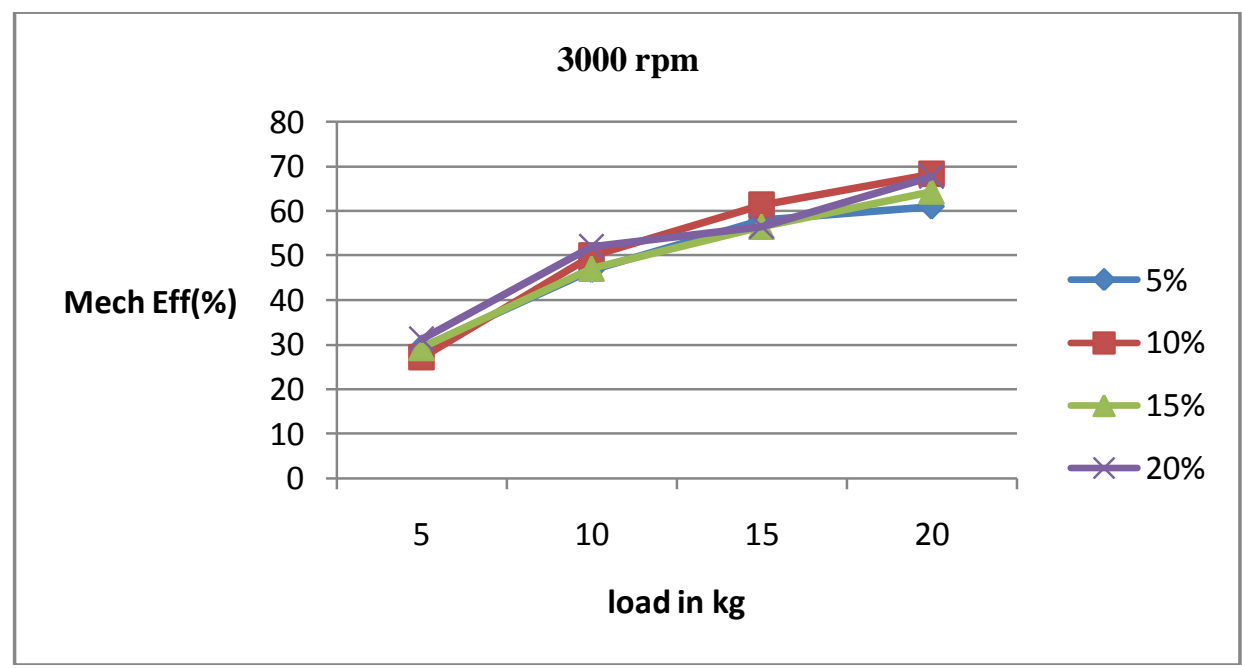

Fig 5.2.5 Variation of Mechanical Efficiency with load at $3000 \mathrm{rpm}$

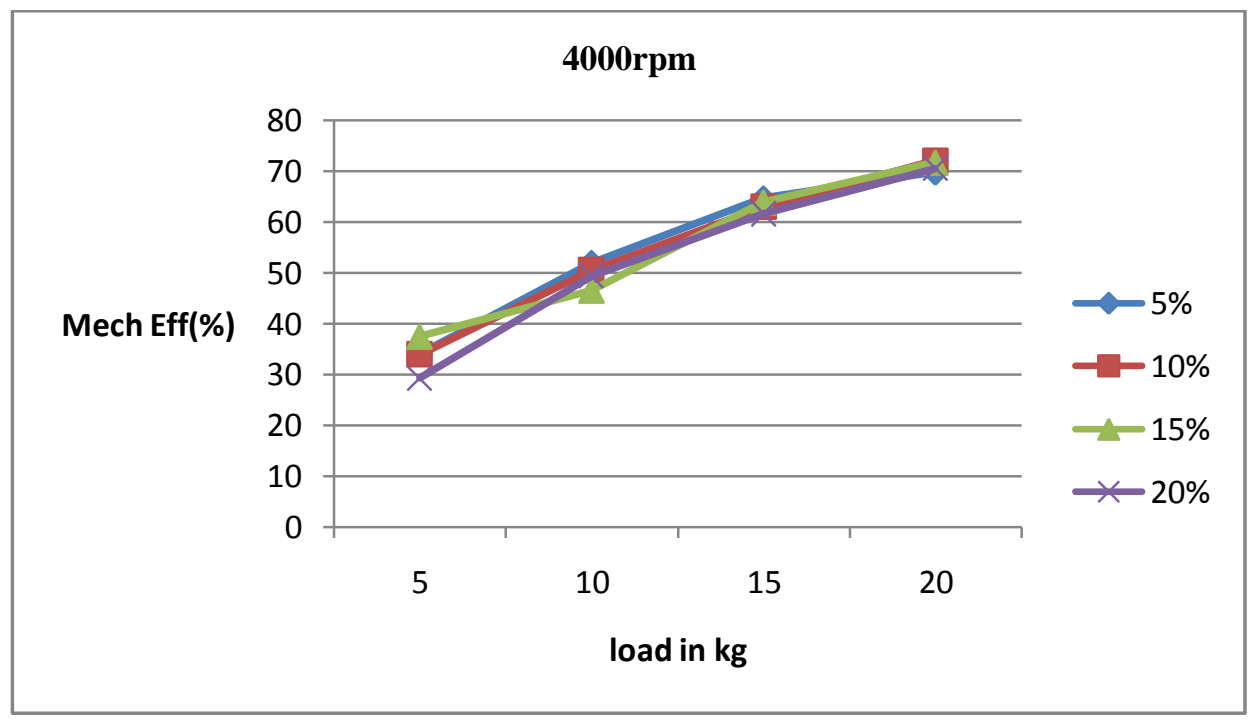

Fig 5.2.6 Variation of Mechanical Efficiency with load at 4000 rpm 


\section{Conclusion}

From the results, it can be concluded that Ethanol blends are quite successful in replacing pure Gasoline in Spark Ignition Engine. Results clearly show that there is an increase in Specific Fuel Consumption because of low calorific Value of Ethanol than Gasoline and also increase in the mechanical efficiency. So from the curves it is seen that $10 \%$ ethanol blended Gasoline is the best choice for use in the existing Spark Ignition Engines without any modification to increase Efficiency. A little consideration has to be taken on material used as maximum pressure inside cylinder is increased by blending. A balance has to be made between Specific Fuel Consumption and efficiency to take care of users using blend as more fuel will be consumed due to blending of ethanol with gasoline.

\section{References}

[1]. Demain, A. L., "Biosolutions to the energy problem," Journal of Industrial Microbiology \& Biotechnology, 36(3), 2009. 319-332.

[2]. Festel, G. W., "Biofuels - Economic Aspects," Chemical Engineering \& Technology. 31(5), 2008, $715-720$.

[3]. Wallner, T., Miers, S. A., and McConnell, S., "A Comparison of Ethanol and Butanol as Oxygenates Using a Direct-Injection, Spark-Ignition Engine,” Journal of Engineering for Gas Turbines and Power. 131(3), 2009

[4]. GrabysJuozas, influence of composition of gasoline - ethanol blend parameters of internal combustion engines,journal of kones, internal combustion engines vol. 10, 2003, 3-4.

[5]. He Bang-Quan,WangJian-Xin studied emission characteristics of an efficient engine with ethanol blended gasoline, atmospheric env 37,(2003), 949-957.

[6]. Pal Amit, Maji S., Sharma O.P. and Babu M.K.G.,"Vehicular Emission Control Strategies for the Capital City of Delhi", India, January 16-18, 2004, SAE Paper no 2004-28-0051

[7]. Hubballi P.A. and BabuT.P.Ashok, effect of aqueous denatured spirit on engine performance and exhaust emissions, SAE 2004-280036 .

[8]. N. Seshaiah, Efficiency and exhaust gas analysis of variable compression ratio spark ignition engine fuelled with alternative fuels, international journal of energy and environment Volume 1, Issue 5, 2010, 861-870.

[9]. Bayraktar Hakan, experimental and theoretical investigation of using gasoline ethanol blends in spark-ignition engines, renewable energy 30, (2005), 1733-1747. 